\title{
Evaluation of damage, food attractants and population dynamics of strawberry sap beetle
}

\author{
Rodrigo A Fornari'; Ruben Machota Junior²; Daniel Bernardi ${ }^{3}$; Marcos Botton ${ }^{4}$; Patrik Luiz Pastori ${ }^{5}$ \\ ${ }^{1}$ UFSM, Campus Universitário, 97105-900 Santa Maria-RS; digofornari@gmail.com; ${ }^{2}$ UFPel, Depto. Fitossanidade, C. Postal 354, \\ 96010-900 Pelotas-RS; ruben_soad@yahoo.com.br; ${ }^{3}$ ESALQ/USP, Depto. Entomologia, 13418-900 Piracicaba-SP; dbernardi2004@ \\ yahoo.com.br; ${ }^{4}$ Embrapa Uva e Vinho, C. Postal 130, 95700-000 Bento Gonçalves-RS; marcos.botton@embrapa.br; ${ }^{5}$ UFC, Dept ${ }^{\circ}$ Fitotec- \\ nia, 60356-000 Fortaleza-CE; plpastori@ufc.br (corresponding author).
}

\begin{abstract}
The strawberry sap beetle [Lobiopa insularis (Coleoptera: Nitidulidae)] is one of the most important pests of strawberry crops. This study aimed to determine the relationship between strawberry fruit maturation stages and the feeding of sap beetle in laboratory and to evaluate food attractants and population dynamics of this species during the crop season. To evaluate the feeding preference of strawberry fruits 'Camarosa' at different maturation stages [green $(\mathrm{G})$, semi-ripe (SM) and ripe (R)] were exposed to adult sap beetles in plastic cups. We evaluated in field the effect of food baits and pest fluctuation with traps baited with different food baits: (T1) ripe ground strawberries; (T2) cattle feed, granulated sugar and water; (T3) $\mathrm{T} 1$ and $\mathrm{T} 2$ attractants mixed at 1:1 ratio; (T4) fruit mix, granulated sugar, water and beer, sprayed with isoamyl-acetate and (T5) control (no food attractants and insecticide). In all treatments the insecticide Malathion $1000^{\circledR} \mathrm{CE}$ was mixed. The population dynamics of adult beetles were monitored during throughout the cycle of strawberry culture in the municipalities of Caxias do Sul and Bom Princípio, Rio Grande do Sul state, Brazil, using the best food baits for catching adults of the pest. There was no significant difference in relation to the feeding of sap beetle adults in any of the maturation stages, 96 hours after infestation, with no significant increase in feeding on ripe strawberries. In the field, traps baited with ripe strawberries were effective in attracting insects for seven days, with the first occurrence of the pest in June in the municipality of Caxias do Sul and in August in Bom Princípio, with population peaks during January in both experiments.
\end{abstract}

Keywords: Fragaria $x$ ananassa, Lobiopa insularis, Nitidulidae, baiting, population fluctuation, traps.

\section{RESUMO}

Avaliação de danos, atrativos alimentares e dinâmica populacional da broca-do-morango

Lobiopa insularis (Coleoptera: Nitidulidae) é uma importante praga pelos prejuízos ocasionados aos frutos de morango. Neste estudo, objetivou-se avaliar a suscetibilidade de frutos de morango em diferentes estádios de maturação ao dano provocado pelo adulto da broca do morango em laboratório e o efeito de atrativos alimentares e flutuação populacional da praga em lavouras comerciais de morangueiro. Para avaliar a preferência alimentar, frutos de morango cv. Camarosa em diferentes estádios de maturação [verde $(\mathrm{G})$; semi-maduros (SM) e maduros (R)] foram oferecidos para adultos da broca do morango em copos plásticos. Em campo, avaliou-se o efeito de atrativos alimentares e a flutuação populacional da praga, com armadilhas iscadas com diferentes atrativos alimentares: (T1) morangos maduros triturados; (T2) ração de vaca leiteira, açúcar cristal e água; (T3) atrativos T1 e T2 misturados na proporção 1:1; (T4) composto de frutas, água, açúcar cristal e cerveja, borrifando a mistura com acetato de isoamila e (T5) controle (sem atrativos alimentares e com inseticida). Em todos os tratamentos foi misturado o inseticida Malathion $1000^{\circledR} \mathrm{CE}$. A flutuação populacional dos besouros adultos foi monitorada durante todo o ciclo da cultura nos municípios de Caxias do Sul e Bom Princípio, Rio Grande do Sul, utilizando o melhor atrativo alimentar para a captura de adultos da praga. Não houve diferença significativa em relação à alimentação de adultos da broca do morango, em todos estádios de maturação, 96 horas após a infestação, com incremento, não significativo, na alimentação em morangos maduros. Em campo, verificou-se que armadilhas iscadas com morangos maduros foram eficientes na atração de insetos por sete dias, com as primeiras ocorrências da praga nos meses de junho no município de Caxias do Sul e em agosto, em Bom Princípio, com picos populacionais durante janeiro em ambos os locais estudados.

Palavras-chave: Fragaria $x$ ananassa, Lobiopa insularis, Nitidulidae, atrativo alimentar, flutuação populacional, armadilhas.

\section{(Recebido para publicação em 4 de novembro de 2012; aceito em 26 de junho de 2013)} (Received on November 4, 2012; accepted on June 26, 2013)

$\mathrm{T}$ he strawberry sap beetle [Lobiopa insularis (Coleoptera: Nitidulidae)], is one of the most important pests of commercial strawberry crops in Brazil and world, causing major damage to fresh market strawberries (Williams \& Salles, 1986; Rondon et al., 2004; Kovaleski et al., 2006; Strand, 2008;
Rondon et al., 2011) being a challenge to farmers (Henz, 2010).

These insects feed and lay eggs inside strawberry fruits (Price, 2004) with food preferences of fruits and vegetables similar to those of Stelidota geminata (Coleoptera: Nitidulidae) (Lasoń \& Przewozny, 2009). The damage can be caused by the larvae and by adults (Rondon et al., 2011), attacking mainly those located close to the ground (Rhainds \& EnglishLoeb, 2002; Loughner et al., 2007a). These beetles are attracted by volatiles dispersed during fruit ripening (Myers, 2008; Guimarães et al., 2009). In 
addition to the direct damage, they also serve as fungal dispersal agents, increasing yield losses (Williams \& Salles, 1986; Salles, 2005; Rondon et al., 2011). Sap beetles can also vector mycotoxin producing secondary fungi development in strawberries (Dowd \& Nelson, 1994). Studies have shown that crops usually grown in the soil are affected by higher occurrence rates of sap beetle than semi-hydroponic strawberries (Rhainds \& English-Loeb, 2002; Kovaleski et al., 2006). The bulk of sap beetle damages can be seen during harvesting time (Williams \& Salles, 1986).

In order to implement an integrated pest management program for sap beetle in strawberry crops, first, it is necessary to have information on monitoring strategies for the species in order to define the correct timing of pest control. The current recommendation for the monitoring of strawberry sap beetle is the placement of baited pitfall traps on the ground between crop beds until the top opening of the trap is leveled with the soil due to foraging movements of adults of Nitidulidae in the soil (Rhainds \& English-Loeb, 2002). The trap is baited with a mix of dairy cattle feed $(5 \mathrm{~kg})$, granulated sugar (500 g), Malathion $1000^{\circledR} \mathrm{CE}(4 \mathrm{~mL} / \mathrm{L})$ insecticide and water $(5 \mathrm{~L})$ (Salles \& Williams, 1983). However, there is currently no information on the lifespan or efficacy of this baiting strategy, or of any other baits used to capture sap beetle in the field. Knowledge about bait efficacy and its residual effect in the field would allow a better understanding of population dynamics of sap beetle, useful information for pest management and control.

This study aimed to determine the relationship between strawberry fruit maturation stages and the feeding of sap beetle and to evaluate food attractants used as bait to monitor sap beetle and understand population dynamics of this species during the crop season.

\section{MATERIAL AND METHODS}

Evaluation of damage caused by adult sap beetles on 'Camarosa' strawberries at different maturation stages [green $(\mathrm{G})$, semi-ripe $(\mathrm{SM})$ and ripe $(\mathrm{R})]$ were collected from a commercial crop field located in the municipality of Caxias do Sul, Rio Grande do Sul State, Brazil (29¹2'08'S; 5057'19'" W) and transported to the laboratory. In laboratory the fruits were then analyzed for $\mathrm{pH}$ (AOAC, 2005) and Total Soluble Solids (TSS) (Pregnolatto, 1985). The fruits classified as Green $(\mathrm{G})$ were $100 \%$ green in color, with $\mathrm{pH}=3.3$ and $\mathrm{TSS}=$ 6.82; Semi-ripe (SM) fruits were up to $30 \%$ red in color, with $\mathrm{pH}=3.4$ and $\mathrm{TSS}=7.16$ and Ripe (R) fruits were $100 \%$ red in color, with $\mathrm{pH}=3.5$ and $\mathrm{TSS}=7.39$. Individual fruits were placed in $300 \mathrm{~mL}$ plastic containers, with 15 repetitions per treatment $(\mathrm{G}, \mathrm{SM}$, and $\mathrm{R})$. Each fruit was infested with a fieldcollected adult of sap beetle of unknown sex and age, where they were kept at $23 \pm 3^{\circ} \mathrm{C}, 70 \pm 10 \%$ relative humidity and 14 hours photophase. The fruit damage (\%) was evaluated after 24, 72 and $96 \mathrm{~h}$. Food attractants are used in commercial strawberry fields as baits for monitoring the presence of adult sap beetles.

This experiment started on February $11^{\text {th }}, 2008$, in Caxias do Sul, at a commercial 'Aromas' strawberry field planted at $60 \times 45 \mathrm{~cm}$ spacing (lines $\mathrm{x}$ plants) and located in a shallow tunnel naturally infested by strawberry sap beetle. Food attractants used as bait were evaluated by placing pitfall traps made of plastic containers $(13 \times 10 \times 5 \mathrm{~cm})$. The traps were perforated with 8 holes of $8 \mathrm{~mm}$ diameter on the lid to allow the insects to access the interior of the container. The traps were placed within crop beds, with lids leveled with the soil, approximately $10 \mathrm{~m}$ apart from each other. A 16x13 cm piece of wood was placed approximately $2 \mathrm{~cm}$ above the traps to reduce exposure of containers to direct sunlight. The food attractants used were: $\mathrm{T} 1=$ ripe strawberries $(300$ $\mathrm{g} / \mathrm{L}$ water); $\mathrm{T} 2=$ dairy cattle feed $(5 \mathrm{~kg})$, granulated sugar (500 g), and water (5 L), as suggested by Salles \& Williams (1983); T3 $=\mathrm{T} 1$ and $\mathrm{T} 2$ mixed at 1:1 ratio; $\mathrm{T} 4=$ fruit mix (two apples, ten peaches, one grape cluster), water (1 L), granulated sugar (500 g), and beer $(1.5 \mathrm{~L})$, which was sprayed with isoamyl acetate as suggested by Biezanko (1938) and $\mathrm{T} 5=$ control (water + Malathion $1000^{\circledR} \mathrm{CE}$ insecticide $\left.(4 \mathrm{~mL} / \mathrm{L})\right)$. Each pitfall trap was baited with $250 \mathrm{~mL}$ of the corresponding attractant, and Malathion $1000^{\circledR} \mathrm{CE}(4 \mathrm{~mL} / \mathrm{L})$ was then added to each trap. The insecticide Malathion $^{\circledR}$ was used because it was recommended for strawberry in Brazil, but is currently not (Agrofit, 2013) and preliminary data showed lethal activity of the insecticide on sap beetle. The experimental design was randomized complete blocks, with ten replications. The number of adult sap beetles in each trap was counted each seven days after the placement of the trap in the field.

Exposure time to strawberry juice on the capture of adult sap beetle - Starting on March $2^{\text {nd }}, 2008$, strawberry fruit juice was prepared weekly, mixed with Malathion ${ }^{\circledR}$ (4 $\mathrm{mL} / \mathrm{L}$ ) and placed in pitfall traps as described above. The traps were then baited and exposed to room temperature for 7, 14, 21 or 28 days in the laboratory and placed in the field according to a randomized complete block design with five replications. The traps were set 10 $m$ apart from each other, and the number of adults of sap beetle in each trap was counted seven days after the placement of the trap in the field. Two controls were used in this experiment: a trap baited with a mix made on the day the traps were set in the field and an empty trap.

Population dynamics of sap beetle in strawberry crops - Once the effect of each food attractant was evaluated and time effects were determined for the strawberry fruit juice bait, an experiment was set up to determine population dynamics of adult sap beetles during a crop season in the municipalities of Caxias do Sul and Bom Princípio. These two locations were chosen because they are major strawberry producers in Rio Grande do Sul. In both fields, 'Aromas' strawberries were planted in April 2008, spaced $60 \times 45 \mathrm{~cm}$ in a shallow tunnel. The total sampled area was $87,823 \mathrm{~m}^{2}$ in Caxias do Sul and 5,315 $\mathrm{m}^{2}$ in Bom Princípio. Population dynamics were evaluated from May 2008 to February 2009, each time the farmers cleared the fields. We changed food attractant bait, collected, identified and counted the number of adult of sap beetle in each 
trap weekly.

For insect capture, ten pitfall traps placed at least $10 \mathrm{~m}$ apart from each other were used. The traps were baited with $\mathrm{T} 1=$ ripe ground strawberries (300 $\mathrm{g} / \mathrm{L}$ water) and the Malathion $1000^{\circledR} \mathrm{CE}$ insecticide $(4 \mathrm{~mL} / \mathrm{L})$.

Meteorological data for Caxias do Sul were obtained from the 'Estação Meteorológica da Fundação Estadual de Pesquisa Agropecuária (FEPAGRO)'. Bom Princípio does not have such facilities, so meteorological data were obtained from a state station in the neighboring town of Campo Bom, Rio Grande do Sul State, located approximately $36 \mathrm{~km}$ from the strawberry field of Bom Princípio.

All data were tested for normality (Shapiro \& Wilk, 1965) and submitted to an analysis of variance and compared by Tukey test $(\mathrm{p} \leq 0.05)$, using the software SAS $^{\circledR}$ (SAS Institute, 1989).

\section{RESULTS AND DISCUSSION}

Although no significant difference, 24, 48, 72, and $96 \mathrm{~h}$ after fruits were exposed to sap beetle, there was a slight increase in the percentage of fruit damage: green fruits with $76.0 \%$, semi-ripe fruits presented $92.0 \%$ and ripe fruits $100.0 \%(\mathrm{p}>0.1660)$ (Figure 1). After $48 \mathrm{~h}$ of exposure to insects, $100 \%$ of semi-ripe and ripe fruits were damaged while green fruits showed $82.3 \%$ damage, which remained unchanged for up to 96 hours (Figure 1). All lesions caused by insect feeding on the fruit increased in quantity and size, regardless of the fruit maturation stage. Oviposition was observed in ripe fruits after 24 hours of insect exposure.

These results expand those obtained by other researchers (Loughner et al., 2007a; Guimarães et al., 2009) who concluded that sap beetles (larvae and adults) preferentially attack ripe fruits and feed on fruit pulp, making them useless for marketing. Similar results were observed in the United States for Stelidota geminata (Coleoptera: Nitidulidae) that also attacks ripe fruits or rot in the field (Loughner et al., 2007a, 2007b, 2008; Myers, 2008).

A greater number of adult strawberry sap beetles (approximately 65\% of individuals) was captured using the fruit mix (T4), which was different $(p \leq 0.05)$ from the strawberry fruit juice (T1), which captured about $25 \%$ of individuals (Figure 2a). Dairy cattle feed as bait (T2) captured $20 \%$ of individuals, which was not different from $\mathrm{T} 1$ and T3 capturing only $5 \%$ of the insects (Figure 2a). In the control (T5), no sap beetles were captured (Figure 2a). Based on these results, the fruit mix, water, granulated sugar, beer sprayed with isoamyl acetate (T4) was efficient for monitoring sap beetles in strawberry fields. The ripe ground strawberries (T1), dairy cattle feed granulated sugar recommended by Salles \& Williams (1983) (T2) and T1 and T2 mixed at 1:1 ratio (T3) were also effective to monitor the presence of sap beetles in the field.

According to Biezanko (1938), Lepidoptera are attracted to volatiles emitted by fruit ripening, showing a similar behavior to sap beetles, which explains the attraction of this species. However, due to the easiness to obtain all the ingredients necessary to make the ripe ground strawberries (T1) bait throughout the year, it was selected as the most viable option for the monitoring of strawberry sap beetle. Ripe ground strawberries bait can be prepared from discarded strawberries, avoiding the need for additional purchases, thereby reducing costs.

After days in the field, the attractant based on strawberry fruits lost its attractiveness, gradually diminishing the number of trapped insects, compared to 14 days after exposure. This decline remained until 21 and 28 days after exposure (Figure 2b). Nevertheless, there was no difference in captured numbers when comparing the bait exposed for a week to field conditions with the freshly made control trap (Figure 2b). There was no capture of adult beetles by the 28-day-old juice or the empty control trap (Figure 2b).

The evaluation of strawberry juice at different times of exposure in the field allowed to observe a significant decrease in captures over time. After seven days of field exposure, the bait lost its attractiveness, gradually reducing the number of captures. This indicates that the bait should be changed within this period. This occurs because of the large number of ripe strawberries available

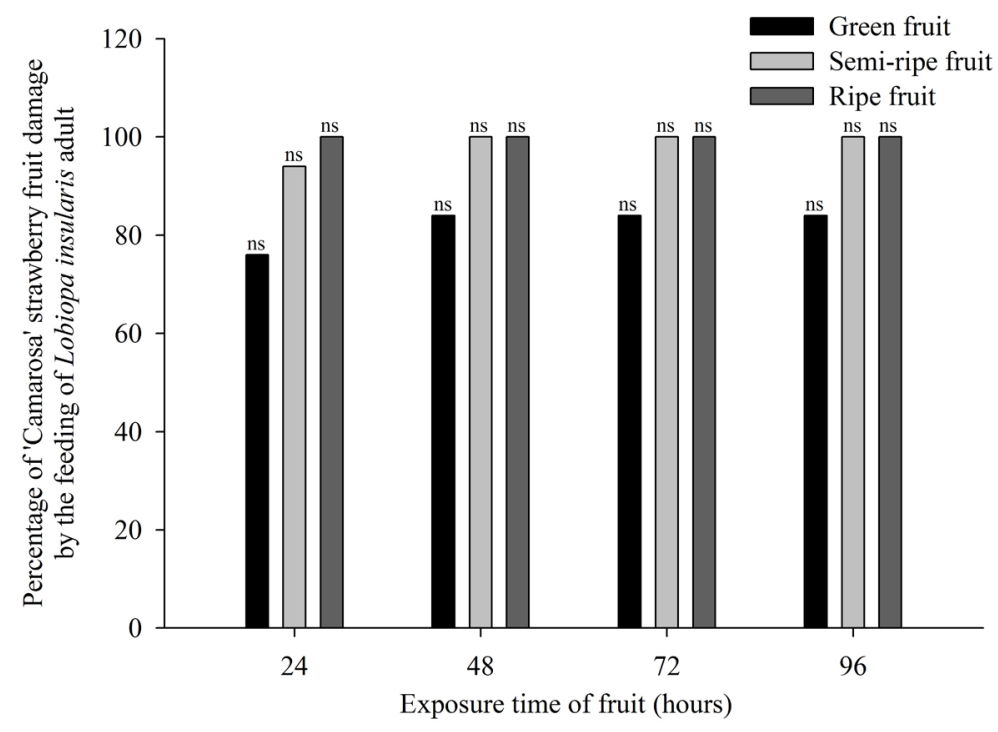

Figure 1. 'Camarosa' strawberry fruits (\%) damaged by Lobiopa insularis (Coleoptera: Nitidulidae) feeding in the laboratory [frutos de morango cv. 'Camarosa' (\%) danificados pela alimentação de Lobiopa insularis (Coleoptera: Nitidulidae) em laboratório]. ( $\mathrm{T}=23 \pm 3^{\circ} \mathrm{C}$; $\mathrm{RH}=70 \pm 10 \%$; photophase $=14 \mathrm{~h})$. ( ns = not significant by $\mathrm{F}$ test $(\mathrm{p}>0.01)$ for groups-withintreatments effects). Santa Maria, UFSM, 2008-2009. 


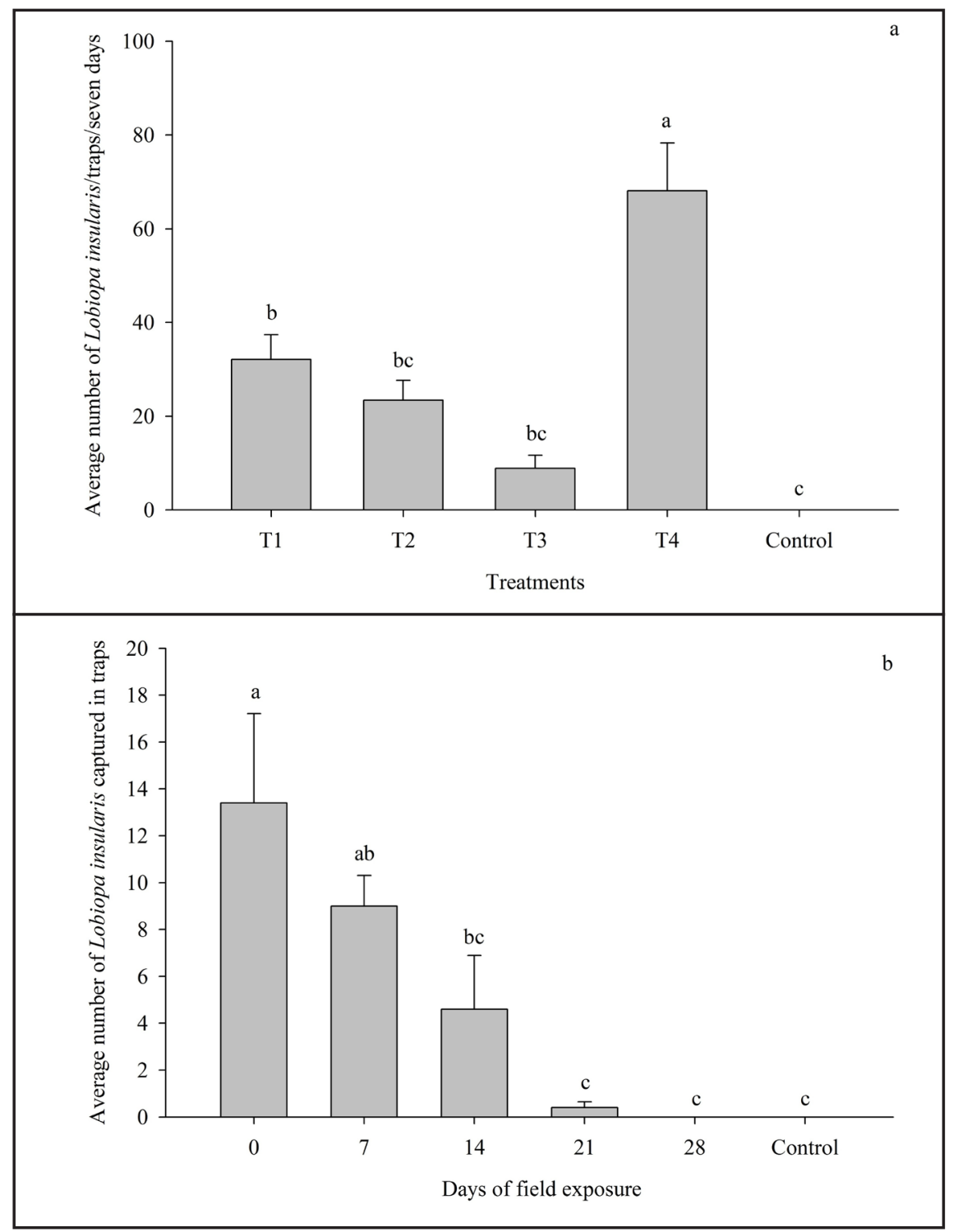

Figure 2. Average number of Lobiopa insularis (Coleoptera: Nitidulidae) captured after seven days of exposure to different food attractants $[\mathrm{T} 1=$ ripe strawberries; $\mathrm{T} 2=$ dairy cattle feed, granulated sugar, and water; $\mathrm{T} 3=\mathrm{T} 1$ and $\mathrm{T} 2$ mixed at 1:1 ratio; $\mathrm{T} 4=$ fruit mix, water, granulated sugar and beer, which was sprayed with isoamyl acetate and control (water + Malathion $1000^{\circledR} \mathrm{CE}$ ). In all treatments was mixed the insecticide Malathion $1000^{\circledR} \mathrm{CE}$ ] in Bento Gonçalves-RS, Brazil, 2009 (a) and strawberry juice prepared at different times in Caxias do Sul-RS, Brazil, 2008 (b) used as bait in Pitfall traps in 'Aromas' strawberry fields \{Número médio de Lobiopa insularis (Coleoptera: Nitidulidae) capturados após sete dias de exposição a diferentes atrativos alimentares [(T1) morangos maduros triturados; (T2) ração de vaca leiteira, açúcar cristal e água; (T3) atrativos T1 e T2 misturados na proporção 1:1; (T4) composto de frutas, água, açúcar cristal e cerveja, borrifando a mistura com acetato de isoamila e controle (água + inseticida Malathion $1000^{\circledR} \mathrm{CE}(4 \mathrm{~mL} / \mathrm{L})$. Em todos os tratamentos foi misturado o inseticida Malathion $1000^{\circledR}$ CE.] em Bento Gonçalves-RS, Brasil, 2009 (a) e suco de morango com diferentes períodos de preparo em Caxias do Sul-RS, Brasil, 2008 (b) usados como isca em armadilhas Pitfall em morangueiros cv. 'Aromas'\}. [Averages followed by different letters are significant (Tukey, 5\%)].Santa Maria, UFSM, 2008-2009.

in the field during the season, thus reducing the effectiveness of traps with strawberry juice.

The first adults of sap beetle were
January, with an average of $93.6 \pm 4.1$ insects/trap/week in Caxias do Sul and $38.1 \pm 3.3$ insects/trap/week in Bom Princípio. However, adult captures started to intensify in the month of October in Caxias do Sul and December in Bom Princípio (Figures 3a and 3b). In both sites, there was a significant decrease in the number of insects trapped during the month of February due to a decreased number of available fruits in both municipalities (Figure 3a and $3 b$ ). The months of December and January are characterized by increased temperatures favoring growth and, consequently, population density of sap beetle (Figure 3a and 3b). Furthermore, the highest fruit yield in field is observed from August to December (Cantillano, 2005).

Williams \& Salles (1986) observed for L. insularis that the insect flies to the field during the beginning of fruit harvesting, but at reduced numbers probably related to the low temperature (Loughner et al., 2008) in this period. If a strategy of pitfall traps were implemented as a control strategy, the beginning of fruit harvesting would be a good time for placing the traps in the field to capture the first adult beetles that move to the fields, reducing potential damage to fruits. Markrecapture experiments showed that adults can move 17 and $50 \mathrm{~m}$ within a crop of strawberries and fallow fields, respectively (Loughner et al., 2007b), indicating that adults have enough mobility to choose between cultivars in the plot sampled and the rapid entry of overwintering adults into fields in this study indicate that beetles are quite capable of flying (Loughner et al., 2008). Understanding the strawberry sap beetle movement and migration facilitates pest management strategies such as biological or cultural control methods, or the use of toxic baits (Williams et al., 1996; Loughner et al., 2008).

From August to December, farmers report the greatest damage caused by the strawberry sap beetle and usually apply insecticides, mainly pyrethroids, for its control. The variation of infestation time between the two sites also indicates that capture and monitoring depend 


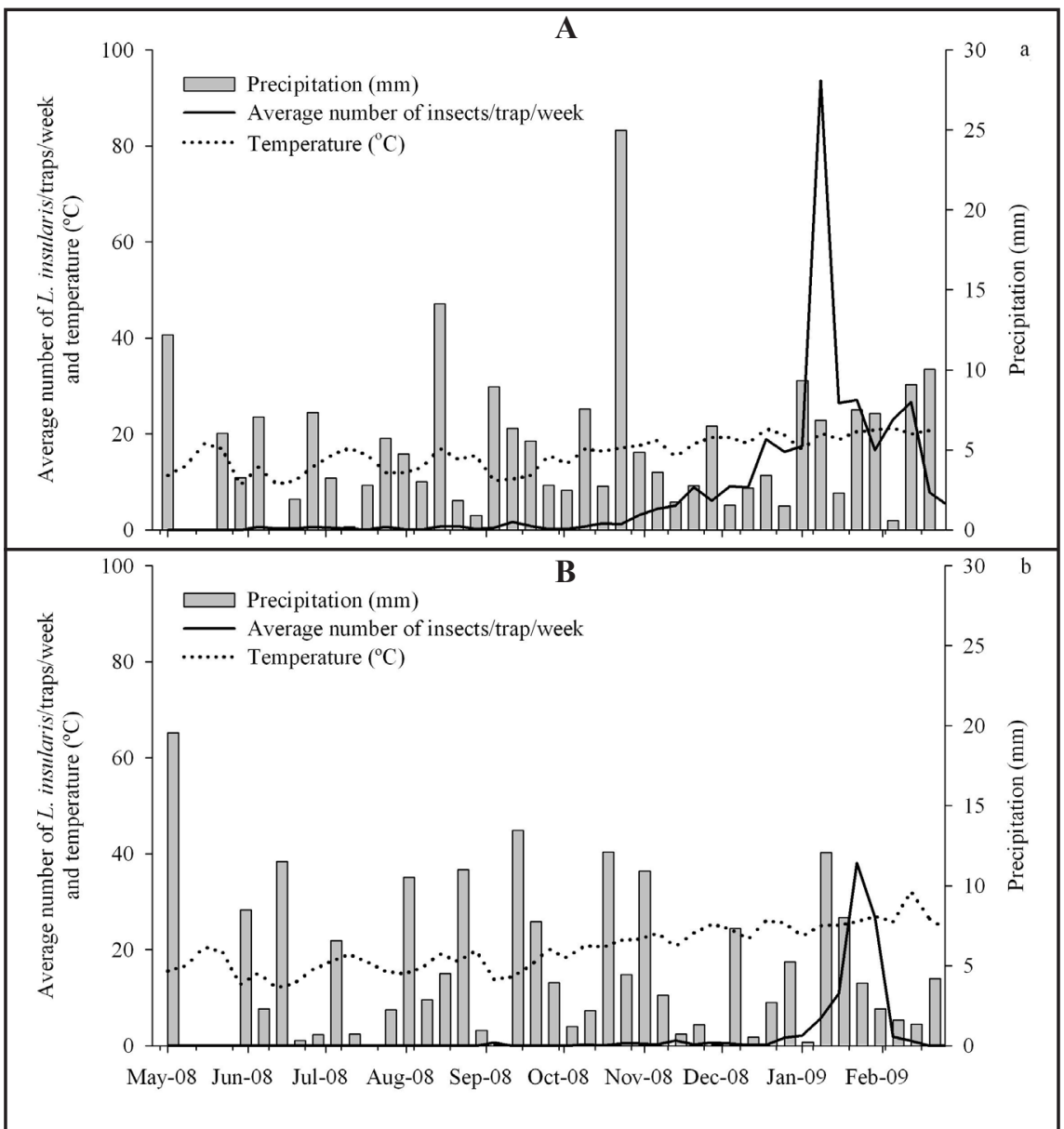

Figure 3. Population dynamics of adult of Lobiopa insularis (Coleoptera: Nitidulidae) in strawberry in Caxias do Sul (a) and Bom Princípio (b), RS, Brazil, from May 2008 to February 2009 [dinâmica populacional de adultos de Lobiopa insularis (Coleoptera: Nitidulidae) em morangueiro em Caxias do Sul (a) e Bom Princípio (b), RS, Brasil, Maio de 2008 a Fevereiro de 2009]. Santa Maria, UFSM, 2008-2009.

on the location of the strawberry field, reinforcing the importance of monitoring at each site. Factors that affect strawberry sap beetle densities were more connected with individual farms than with geographic location (Loughner et al., 2007a). The period of intense harvesting extends throughout December, therefore a large number of ripe fruits is found in the field, contributing to the increased insect population in January.

February is usually the time when farmers remove strawberry plants for the planting of a new crop in April or May. However, strawberry sap beetles successfully overwintered in wooded habitats, blueberry and raspberry, but not in strawberry (Loughner et al., 2007a). The food and overwintering resources provided by other crops and wooded habitat adjacent to strawberry fruit production in the field. However, it is possible to monitor sap beetle population with traps baited with strawberry juice, using these traps as a way to indicate when to treat or to use traps as a pest control strategy in strawberry fields.

\section{ACKNOWLEDGEMENTS}

To "Conselho Nacional de Desenvolvimento Científico e Tecnológico (CNPq)", "Coordenação de Aperfeiçoamento de Pessoal de Nível Superior (CAPES)" and "Fundação de Amparo à Pesquisa do Estado do Rio Grande do Sul (FAPERGS)" for supporting this research.

\section{REFERENCES}

AgROFIT (Sistema de Agrotóxicos Fitossanitários) - Ministério da Agricultura e Pecuária. 2013, 28 May. Available in <http:/ www.agricultura.gov.br/>

AOAC (ASSOCIATION OF OFFICIAL ANALYTICAL CHEMISTS). 2005. Official Method of Analysis. $18^{\text {th }}$ ed. Washington, D.C.

BIEZANKO CM. 1938. Sobre as iscas que se usam para atrair os lepidópteros e algumas outras questões que se relacionam com este assunto. Chácaras e Quintais 58: 62-63.

CANTILLANO RFF. 2005. Colheita e póscolheita. In: Sistema de produção do morango. Bento Gonçalves: Embrapa Uva e Vinho (Sistemas de Produção 5). 2005, 30 June. Available in http://sistemasdeproducao. cnptia.embrapa.br/FontesHTML/Morango/ SistemaProducaoMorango/cap12.htm

DOWD PF; NELSON TC. 1994. Seasonal variation of sap beetle (Coleoptera: Nitidulidae) populations in central Illinois cornfield-oak woodland habitat and potential influence of weather patterns. Environmental Entomology 23: 1215-1223.

GUIMARÃES JA; MICHEREFF FILHO M; RIBEIRO MGPM; LIZ RS; GUEDES ÍMR. 2009. Ocorrência e manejo da broca-domorangueiro no Distrito Federal. Brasília: Embrapa Hortaliças, 5pp. (Comunicado Técnico 74).

HENZ GP. 2010. Desafios enfrentados por agricultores familiares na produção de morango no Distrito Federal. Horticultura Brasileira 28: 260-265.

KOVALESKI A; FERLA NJ; BOTTON M; PINENT SMJ. 2006. Aspectos fitossanitários. In: Produção de morangos no sistema semihidropônico. Bento Gonçalves: Embrapa Uva e Vinho (Sistemas de Produção 15). 2006, 30 June. Available in http://www.cnpuv.embrapa. $\mathrm{br} /$ publica/sprod/MorangoSemiHidroponico

LASOŃ A; PRZEWOZNY M. 2009. Lobiopa insularis (Castelnau, 1840) (Coleoptera: 
Nitidulidae: Nitidulinae) - an introduced beetle species new for the Palaearctic fauna. Polish Journal of Entomology 78: 347-350.

LOUGHNER RL; LOEB GM; DEMCHAK K; SCHLOEMANN S. 2007a. Evaluation of strawberry sap beetle (Coleoptera: Nitidulidae) use of habitats surrounding strawberry plantings as food resources and overwintering sites. Environmental Entomology 36: 10591065.

LOUGHNER RL; LOEB GM; TURECHEK WW. 2007b. Strawberry sap beetle (Coleoptera: Nitidulidae) distribution in New York and differential movement in two types of habitat. Journal of Entomological Science 42: 603609.

LOUGHNER RL; LOEB GM; SCHLOEMANN S; DEMCHAK K. 2008. Evaluation of cultural practices for potential to control strawberry sap beetle (Coleoptera: Nitidulidae). Journal of Economic Entomology 101: 850-858.

MYERS L. 2008. Sap beetles (of Florida), Nitidulidae (Insecta: Coleoptera: Nitidulidae). University of Florida-IFAS, Cooperative Extension Service, EENY-256. 2008, 28 Jule. Available in http://edis.ifas.ufl.edu/IN525
PREGNOLATTO W. 1985. Normas analíticas do Instituto Adolfo Lutz: Métodos químicofísicos para análise de alimentos. $3^{\text {th }}$ ed. São Paulo: Instituto Adolfo Lutz. v. 2.

PRICE JF. 2004. Adult and larval large sap beetle (picnic beetle, nitidulid), Lobiopa insularis. 2004, 18 December. Available in http://strawberry.ifas.ufl.edu/entomology/ damaging 1 full.htm

RHAINDS M; ENGLISH-LOEB G. 2002. Impact of insecticide application and mass trapping on infestation by strawberry sap beetles (Coleoptera: Nitidulidae). Journal of Entomological Science 37: 300-307.

RONDON SI; CANTLIFFE DJ; PRICE JF. 2004. The feeding behavior of three generalist predators relative to main strawberry pests. Environmental Entomology 33: 1014-1019.

RONDON SI; PRICE JF; CANTLIFFE DJ. 2011. Sap Beetle (Coleoptera: Nitidulidae) Management in Strawberries. University of Florida. p. 1-4.

SAS INSTITUTE INC. SAS/STAT User's Guide, Version 9. 4th ed., Cary, Carolina do Norte: SAS Institute Inc., 1989.

SALLES LAB; WILLIAMS RN. 1983. Broca- do-morango (Lobiopa insularis). Pelotas: Embrapa-UEPAE de Cascata, 10 pp. (Documentos 17).

SALLES LAB. 2005. Pragas do morangueiro. In: Sistema de produção do morango. Bento Gonçalves: Embrapa Uva e Vinho (Sistemas de Produção 5). 2005, 02 December Available in http://sistemasdeproducao. cnptia.embrapa.br/FontesHTML/Morango/ SistemaProducaoMorango/cap07.htm\#broca

SHAPIRO SS; WILK MB. 1965. An analysis of variance test for normality (complete samples). Biometrika 52: 591-611.

STRAND LL. 2008. Integrated pest management for strawberries. Berkeley: University of California Agriculture and Natural Resources. Publication 3351, $176 \mathrm{pp}$.

WILLIAMS RN; SALLES LAB. 1986. Nitidulidae associated with fruit crops in Rio Grande do Sul, Brazil. Florida Entomologist 69: 298-302.

WILLIAMS RN; ELLIS MS; FICKLE DS; BLOOM ST. 1996. A migration study of Stelidota geminata (Coleoptera: Nitidulidae). The Great Lakes Entomologist 29: 31-35. 